\title{
EFFECT OF THREE EGYPTIAN MEDICINAL PLANT'S EXTRACTS ON BIOCHEMISTRY OF CULEX PIPIENS LARVAE (CULICIDAE: DIPTERA)
}

\author{
By \\ OMNIA MOHAMED HELMY MOHAMED KAMEL ${ }^{1 *}$ \\ AND MOSAAD MOHAMED HASSAN ${ }^{2}$
}

Department of Applied Organic Chemistry, National Research Centre ${ }^{1}$, Dokki, Giza and Department of Entomology, Faculty of Science, Ain Shams University ${ }^{2}$, Cairo

11566, Egypt ( ${ }^{*}$ Correspondence: dromniakamel@yahoo.com)

\section{Abstract}

Culex pipiens is a predominant house-resting mosquito in different countries. Third larval instar of Culex pipiens were exposed to sub-lethal concentration LC25of pet-ether extract for Solenostemma sp, Rosmarinus sp. and Artemisia sp. to study their effect on some enzymatic activities of larvae after 24 hours. AchE enzyme showed high activity in all application extracts. While, showed lower in enzyme activity of $\alpha$-est, $\beta$-est in comparison with control. Glutathione S Transferase showed no difference with control sample. Mixed function oxidase appears high activity with Solenostemma argel and Artemisia sp. While appears low activity with Rosmarinus sp. comparing by control larvae. Finally, these extracts affect the nervous system of tested mosquitoes in different degrees and their energy system and can be used alternate to chemical insecticides in Integrated Vector Management program (IVM).

Key words: Culex pipiens larvae, Medicinal plant extracts, Biological control.

\section{Introduction}

Culex pipiens (Cx. pipiens) is a predominant house-resting mosquito of worldwide distribution (Lane and Crosskey, 1993). In Egypt, the abundance of $C x$. pipiens was reported all-over the country (Mikhail et al, 2009; Abdel-Hamid et al, 2011). No doubt, the Egyptian filariasis (Harb et al, 1993), culicini mosquitoes, mainly $C x$. pipiens transmit Rift Valley fever (El Gebaly, 1978), Sindbis virus (Wilson, 1991) and West Nile Virus (El-Bahnasawy et al, 2013). Apart from diseases transmission, mosquitoes can make human life miserable. Most people of all ages' particularly small children, toddlers and seniors who suffered from Skeeter syndrome experienced a very extreme reaction showed some allergic reaction levels, with itching and redness (Abdel-Motagaly et al, 2017)

The larval stage is the most efficient stage to control mosquito. Using the traditional method for control by chemical insecticides was causing huge hazards on public health (Ansari et al, 2000; Gusmäo et al, 2002; Bakr et al, 2006; 2008). Plant extracts were considered to be the rich source to produce natural safe insecticides alternative to the risky chemical ones (Kamel et al, 2005; Pavela, 2009; El-Maghraby et al, 2012; El- diasty et al, 2014; El-Ghaban et al, 2015; Kamel et al, 2015; Kamel and Hassan, 2015; Hassan and Kamel, 2016). The medicinal plant extracts have different uses for treating many parasitic diseases as ginger and garlic in treatment of mice infected with cryptospori diosis (Abouel-Nour et al, 2016), and DEET as repellent for Cimex lectularis (El Bahansawy et al, 2018), as well as Artemisia апnиa leaf chloroform extract proved to be a strong larvicides against larvae of Anopheles stephensi and Aedes aegypti (Sharma et al, 2014). Also, the Solenostemma sp. ethanolic leaves extract gave marked effect on lipid profile of albino rats which were significantly reduced $(\mathrm{p}<0.05)$ after two weeks of treatment, and high reduced hyper cholesterolemia (Osman et al, 2015). Besides, Artemisia sp. extract has effect on cardiovascular system and was used as anti-hypertensive and to prevent the cardiovascular damages (Ben-Nasr et al, 2013). Artemisia sp. has anti-diabitic effect and treated the blood glucose level with relatively very mild side effects (Dabe and Kefale, 2017). Rosemary (Rosemarinus officinalis L.) has been used in folk medicine to treat headaches, epilepsy, poor circulation, and many other ailments. Besides, it can be used as mild analgesic and can reduce inflammation. The Carnosic acid (CA) 
component has potential antiatherosclerosis effects (Chae et al, 2012). Almost of natural extracts used in the control of insects have effect on the enzymatic activities of treated insects' Glutathione-S-transferases (GSTs), esterases (ESTs), mixed function oxidases (MFO) and acetylcholinesterase (AChE) (Nathan et al, 2005; Feyereisen, 2005; ElKady et al, 2008; Dahi et al, 2009; Gacar and Tasksn, 2009).

The present study was carried out to evaluate the effect of three medicinal plant extracts (Solenostemma argel, Rosemarinus officinalis and Artemisia sp.) on some enzymatic activities to predict the mode of action and could alternate to risky chemical insecticides of insect-vectors control program.

\section{Materials and Methods}

Tested mosquito: Larvae of Culex pipiens collected from the water-body, Abo-Rowash City (Giza Governorate) and immediately transferred to the Experimental Laboratory, Department of Entomology, Faculty of Science, where self-perpetuating colonies were established and maintained under controlled laboratory conditions.

Tested compounds Tested medicinal plants (Solenotemma argle, Rosmarinus officinalis and Artemisia sp.) were collected from noninsecticidal treated cultivated fields, then washed in tap water to remove any dusts and/or dirt then lift to dry under shade in the laboratory. Dried plant (whole plant) were cut into small pieces and ground in an electric grinder. Hundred grams of the resulting powdered materials of each plant were extracted with petroleum ether. The extractions were accomplished by means of a Soxhlet apparatus. The solvent extracts of each plant were evaporated and dried under vacuum using a rotary evaporator of water bath adjusted at $60-70^{\circ} \mathrm{C}$. The resulted dry crude extracts were storage at $4^{\circ} \mathrm{C}$ in screw capped vials, until use.

Biochemical studies: Each of selected compounds was applied on larvae at concentration of $\mathrm{LC}_{25}$ level for $24 \mathrm{hrs}$. Then survived larvae post treatment were gently washed and transferred to labeled pans. Some of these survived larvae and other developmental stages emerged from treated larvae was collected and submitted to biochemical studies.

Preparation of insects for analysis: Insects were homogenized for biochemical analysis in a chilled glass Teflon tissue homogenizer (ST-2 Mechanic-Preczyina, Poland). After homogenation, supernatants were kept in a deep freezer at $-20^{\circ} \mathrm{C}$ till needed. Double Beam Ultraviolet Visible Spectrophotometer (Spectronic 1201, Milton Roy Co., USA) was used to measure absorbance of colored substances or metabolic compounds.

Estimation of acetylcholinesterase: AchE acetylcholinesterase activity was measured after Simpson et al. (1964) using acetylcholine-bromide (AchBr) as substrate. The reaction mixture contained $200 \mu \mathrm{l}$ enzyme solution, $0.5 \mathrm{ml} 0.067 \mathrm{M}$ phosphate buffer $(\mathrm{pH} 7)$ and $0.5 \mathrm{ml} \mathrm{AchBr}(3 \mathrm{mM})$. The test tubes were incubated at $37^{\circ} \mathrm{C}$ for exactly $30 \mathrm{~min}$. $1 \mathrm{ml}$ alkaline hydro-xylamine (equal volume of $2 \mathrm{M}$ hydroxyl-amine chloride \& $3.5 \mathrm{M}$ sodium hydroxide) was added to the tested tubes. Then, $0.5 \mathrm{ml}$ of $\mathrm{HCl}$ (1 part of conc. $\mathrm{HCl} \& 2$ parts of $\Delta \mathrm{H}_{2} \mathrm{O}$ ) was added. The mixture shaken vigorously and allowed to stand for $2 \mathrm{~min}$. $0.5 \mathrm{ml}$ of ferric chloride solution $(0.9 \mathrm{M} \mathrm{Fecl} 3$ in $0.1 \mathrm{MHCl})$ was added and mixed well. The decrease in $\mathrm{AchBr}$ resulting from hydrolysis by AchE was read at $515 \mathrm{~nm}$.

Estimation of non-specific esterases: Alpha esterases ( $\alpha$-esterases) and beta esterases $(\beta$ esterases) were determined (Van Asperen, 1962) using $\alpha$-naphthyl acetate or $\beta$-naphth yl acetate as substrates, respectively. The reaction mixture consisted of $5 \mathrm{ml}$ substrate solution (3x10-4M $\alpha$-or $\beta$-naphthylacetate, $1 \%$ acetone and $0.1 \mathrm{M}$ phosphate buffer, $\mathrm{pH} 7$ ) and $20 \mu \mathrm{l}$ of larval homogenate. The mixture was incubated for exactly $15 \mathrm{~min}$ at $27^{\circ} \mathrm{C}$, then $1 \mathrm{ml}$ of diazoblue color reagent (prepared by mixing 2 parts of $1 \%$ diazoblue B $\& 5$ parts of $5 \%$ sodium lauryl sulphate)was added. The developed color was read at 600 or $555 \mathrm{~nm}$ for $\alpha$ - and $\beta$-naphthol produced 
from hydrolysis of the substrate, respectively. $\alpha$-and $\beta$-naphthol standard curves were prepared by dissolving $20 \mathrm{mg} \alpha$ - or $\beta$-naphthol in $100 \mathrm{ml}$ phosphate buffer, $\mathrm{pH} 7$ (stock solution). Ten milliliters of stock solution were diluted up to $100 \mathrm{ml}$ by the buffer. Aliquots of $0.1,0.2,0.4,0.8 \& 1.6 \mathrm{ml}$ of diluted solution (equal to $2,4,8,16 \& 32 \mu \mathrm{g}$ naphthol) were pippeted into test tubes and completed to $5 \mathrm{ml}$ by phosphate buffer. One milliliter of diazoblue reagent was added and the developed color was measured as mentioned before.

Estimation of the oxidase activity: P-nitroanisole O-demthylation was assayed to determine the mixed function oxidase activity according to the method of Hansen and (Hodgson, 1971) with slight modification. The standard incubation mixture contained $1 \mathrm{ml}$ sodium phosphate buffer $(0.1 \mathrm{M}, \mathrm{pH}$ 7.6), $1.5 \mathrm{ml}$ enzyme solution, $0.2 \mathrm{ml} \mathrm{NADPH}$, (Final concentration $1 \mathrm{mM}$ ), $0.2 \mathrm{ml}$ glucose6-phosphate dehydrogenase (G-6PD). Reaction was initiated by the addition of $p$ nitroanisole in $10 \mu \mathrm{l}$ of acetone to give a final concentration of $0.8 \mathrm{mM}$ and incubated for $30 \mathrm{~min}$ at $37^{\circ} \mathrm{C}$. Incubation period was terminated by addition of $1 \mathrm{ml} \mathrm{HCl}(1 \mathrm{~N})$. Pnitrophenol was extracted with $\mathrm{CHCl} 3$ and $0.5 \mathrm{~N} \mathrm{NaOH}$ and absorbance of $\mathrm{NaOH}$ solution was measured at $405 \mathrm{~nm}$. An extinction coefficient of $14.28 \mathrm{mM}-1 \mathrm{~cm}-1$ was used to calculate 4-nitrophenol concentration.

Table 1: Acetylcholinesterase activity in larvae of $C x$. pipiens treated with medicinal plant extracts at $\mathrm{LC}_{25}$ compared with control:

\begin{tabular}{|c|c|c|c|}
\hline Tested extract & $(\mu \mathrm{g}$ AchBr/min $/ \mathrm{mg}$ protein $)$ Mean \pm SD & T-test At $<0.05$ & Activity ratio \\
\hline S. argel & $685 \pm 15.90$ & $5.35 \times 10^{-13} *$ & 5.39 \\
\hline Rose marinus & $172.67 \pm 4.98$ & $3.81 \times 10^{-9} *$ & 1.36 \\
\hline Artemisia sp. & $649.67 \pm 4.27$ & $2.24 \times 10^{-19} *$ & 5.12 \\
\hline Control & $127 \pm 6.05$ & & \\
\hline
\end{tabular}

Table 2: $\alpha$-Esterases activity in larvae of $C x$. pipiens treated with medicinal plant extracts at $\mathrm{LC}_{25}$ compared with control:

\begin{tabular}{|c|c|c|c|}
\hline Tested extract & $(\mu \mathrm{g} \alpha$-naphthol/min $/ \mathrm{mg}$ protein) Mean $\pm \mathrm{SD}$ & $\mathrm{T}$-test At $<0.05$ & Activity ratio \\
\hline S. argel & $3896.22 \pm 7.04$ & $1.65 \times 10^{-23} * *$ & 0.40 \\
\hline Rose marinus & $7214.44 \pm 3.59$ & $1.99 \times 10^{-22} * *$ & 0.75 \\
\hline Artemisia $\mathrm{sp}$. & $6788.44 \pm 5.44$ & $4.27 \times 10^{-23} * *$ & 0.70 \\
\hline control & $9677.22 \pm 3.46$ & & \\
\hline
\end{tabular}

Table 3: $\beta$-Esterases activity in larvae of $C x$. pipiens treated with medicinal plant extracts at $\mathrm{LC}_{25}$ compared with control:

\begin{tabular}{|c|c|c|c|}
\hline Tested extract & $(\mu g \beta$-naphthol/min $/ \mathrm{mg}$ protein $)$ Mean \pm SD & T-test At $<0.05$ & Activity ratio \\
\hline S. argel & $9.05 \pm 0.46$ & $1.48 \times 10^{-5} *$ & 0.74 \\
\hline Rose marinus & $8.47 \pm 0.58$ & $9.90 \times 10^{-10} *$ & 0.69 \\
\hline Artemisia $s p$. & $4.79 \pm 0.18$ & $2.28 \times 10^{-10} *$ & 0.39 \\
\hline control & $12.2 \pm 0.57$ & & \\
\hline
\end{tabular}


Table 4: Glutathion-s-transferase activity in larval stage of $C x$. pipiens treated with medicinal plant extracts at $\mathrm{LC}_{25}$ compared with control:

\begin{tabular}{|c|c|c|c|}
\hline Tested extract & (umol sub conjugated/min $/ \mathrm{mg}$ protein) Mean \pm SD & T-test At $<0.05$ & Activity ratio \\
\hline S. argel & $60.97 \pm 0.82$ & $4.05 \times 10^{-5} *$ & 0.96 \\
\hline Rose marinus & $61.6 \pm 1.04$ & 0.02 & 0.97 \\
\hline Artemisia sp. & $59.1 \pm 0.70$ & $3.79 \times 10^{-8} *$ & 0.93 \\
\hline control & $63.23 \pm 0.61$ & &
\end{tabular}

Table 5: Mixed function oxidase activity in larval stage of $C x$. pipiens treated with medicinal plant extracts at $\mathrm{LC}_{25}$ compared with control:

\begin{tabular}{|c|c|c|c|}
\hline Tested extract & (umol sub oxidized/min /mg protein) Mean \pm SD & T-test At $<0.05$ & Activity ratio \\
\hline S. argel & $312.33 \pm 2.87$ & $2.91 \mathrm{X} 10^{-17} * *$ & 1.35 \\
\hline Rose marinus & $207.67 \pm 2.05$ & $4.09 \mathrm{X} 10^{-7} *$ & 0.90 \\
\hline Artemisia sp. & $299.67 \pm 2.05$ & $1.22 \mathrm{X} 10^{-10} *$ & 1.30 \\
\hline Control & $231.33 \pm 2.62$ & & \\
\hline
\end{tabular}

$*=$ significantly different $\quad * *=$ high significantly different

\section{Discussion}

In the present study, the highest value of AchE was 685 and the lowest one was 172.67 for Solenostemma sp. and Rosmarinus sp., respectively. The treatment for all extracts showed significant differences between treated larvae and control. These results may be explaining the mortality of larvae. The excess release of AchE which may break down any message to be sent to the receptor and then the insect become without neural orientation (Dahi et al, 2009). In the present study, the highly significant reduction of $\alpha$-esterases in all treatment $C x$. pipiens larvaes compared with control ranged between 3896.22 to 7214.44 for Solenostemma sp. and Rosmarinus sp., respectively. Also, $\beta$-esterases caused significant reduction. The reduction values for high and low treatment were $4.79 \& 9.05$ referred to Artemisia sp. and Solenostemma sp., respectively. The reduction activities which appeared in $\alpha$ - and $\beta$-esterases after treatment with selected plant extracts might be attributed to no detoxification action happen by these enzymes (Abd El-aziz and El-Sayed, 2009). The variation in reduction values probably referred to difference in component of each extract and the susceptibility of $C x$. pipiens to these extracts, the same conclusion was achieved by (Darvishzadeh and Sharifian, 2015) which stated that the esterase enzymes affected by using different insecticides in different degrees according the susceptibility of Tribolium castaneum (Herbst) (Coleoptera: Tenebrionidae). Glutathion-s-transferase activity appeared different degrees of reduction as mentioned in table (4). Solenostemma argel and Artemisia sp. showed significant reduction, 60.97 and 59.1 respectively. Rosmarinus sp. give reduction in the activity but non-significant. The selected extracts inhibit the enzyme activity meaning not play role in detoxification these extracts as insecticide in different degree according their differences of component of each extract. These results agreed with Wang et al. (2014) who stated that the conifer bark and cone extracts and the identified allelochemicals were potent in-vitro inhibitors of GST in Colorado Potato-Beetle larvae. The treatment larvae by medicinal extracts showed significant increase in MFO for Solenostemma sp. and Artemisia sp., 312.33 \& 299.67 respectively. Rosmarinus sp, decreased in the activity compared with control. The increasing of activity might be attributed to their role of detoxification effect to tested extracts by the mean of selfdefense of insect to it (Terriere, 1984). Otherwise, these increasing of activity might be attributed to the fact the tested compound act as juvenile hormone analog were cytochrome P450 inducers in insect (Wilkinson, 1976). Decreasing in the activity of MFO in Rosmarinus sp. application might be to the absent role of detoxification of the compound.

\section{Conclusion}

The outcome data showed that the medicinal plants (Solenostemma argel, Rosemarinus officinalis and Artemisia sp.) beside their effect as medication it can be used as 
insecticides alternate for traditional insecticides or as a synergist to reduce using of chemical pesticides.

The variation of component for extracts reduce the resistant arises as a result for using single component of chemical pesticide.

\section{References}

Abdel-Aziz MF, El-Sayed YA, 2009: Toxicity and biochemical efficacy of six essential oils against Tribolium confusum (Du Val) (Coleoptera: Tenebrionidae). Egypt. Acad. J. Biol. Sci. 2, 2:1-11.

Abdel-Hamid, YM, Soliman, MI, Kenawy, M A, 2011: Geographical distribution and relative abundance of culicine mosquitoes in relation to transmission of lymphatic filariasis in El Menoufia Governorate, Egypt. J. Egypt. Soc. Parasitol. 41, 1:109-18.

Abdel-Motagaly, AME, Mohamad, HM, Morsy, TA, 2017: A mini-review on skeeter syndrome or large local allergy to mosquito bites. J. Egypt. Soc. Parasitol. 47, 2:415-24.

Abouel-Nour, MF, El-Shewehy, DMM, Hamada, SF, Morsy, TA, 2016: The efficacy of three medicinal plants; garlic, ginger and mirazid and a chemical drug metronidazole against Cryptosporidium parvum: ii- Histological changes. J. Egypt. Soc. Parasitol. 46, 1:185-200.

Alghabban, AJ, Eldiasty, JG, Kamel, OMHM, et al, 2015: Evaluation of Rosmarinus species extracted by different solvents against mosquito larvae, Biomophalaria species and some types of microorganisms. J. Adv. Sci. Res. 6, 4: 44-9.

Ansari, MA, Razdan, RK, Mamta, T, Padma, V, Tandon, M, et al, 2000: Larvicidal and repellent actions of Dalbergia sissoo Roxb. (F. Leguminosae); oil against mosquitoes. Bioresource Tech. 73, 3:207-11.

Bakr, RFA, ElBermawy, SM, Geneidy, NAM, Emara, SA, Hassan, HW, et al, 2006: Occurrence of the biological effects of some plant extracts on the cotton leaf worm Spodoptera littoralis (Biosd) and their physiological. Egypt. Acad. Soc. Environ. Develop. 7, 1:109-47.

Bakr, RFA, Hussein, MA, Hamouda, LS, Hassan, HA, Elsokary, ZF, et al, 2008: Effect of some insecticidal agents on some biological aspects and protein patterns of desert locust Schistocerca gregaria (Forskal). Egypt. Acad. Soc. Environ. Develop. 9, 2:29-42.
Ben-Nasr, H, Ben Abderrahim, MA, Salama, M, Ksouda, K, Zeghal, KM, et al, 2013: Potential phytotherapy use of Artemisia plants: Insight for anti-hypertension. J. Appl. Pharma. Sci. 3, 5: 5: $120-5$.

Chae, IG, Yu, MH, Im, NK, Jung, YT, Lee, J, et al, 2012: Effect of Rosemarinus officinalis L. on MMP-9, MCP-1 Levels, and Cell Migration in RAW 264.7 and Smooth Muscle Cells. J. Med. Food, 15, 10:879-86.

Dabe, NE, Kefale, AT, 2017: Antidiabetic Eff ects of Artemisia species: A systematic review. J. Anc. Sci. Life 36, 4:175-81.

Dahi, HF, El-Sayed, YA, El-Barkey, NM, AbdEIAziz, MF, et al, 2009: Toxicological and biochemical studies of methylamine avermactin, a new type of bioinsecticide against the cotton leaf worm, Spodoptera littoralis (Biosd). Egypt. Acad. J. Biol. Sci. 2, 1:103-16.

Darvishzadeh, A, Sharifian, I, 2015: Effect of spinosad and malathion on esterase enzyme activities of Tribolium castaneum (Coleoptera: Tenebrionidae). J. Entomol. Zool. Stud. 3, 2:351-4. El-Bahnasawy, MM, Abdel Fadil, EE, Morsy, TA, 2013: Mosquito vectors of infectious diseases: Are they neglected health disaster in Egypt? J. Egypt. Soc. Parasitol. 43, 2:73-86

Eldiasty, JG, Hassan, MM, Kamel, OMHM, et al, 2014: Evaluation of some agricultural waste extracts against mosquito larvae, and some types of microorganisms as insecticidal and antibiotic agents. Egypt. Acad. J. Biol. Sci. 6, 1:116.

El-Gebaly, RM, 1978: Epidemiological study of outbreak of rift valley fever in military personnel. J. Egypt. Pub. Hlth. Assoc. 53:141-50.

ElKady, GA, Kamel, NH, Mosleh, YY, Bahght, IM, et al, 2008: Comparative toxicity of two bio-insecticides (Spinotoram and Vertemic) compared with Methomyl against Culex pipiens and Anopheles multicolor. World J. Agric. Sci. 4, 2:198-205.

El-Maghraby, S, Nawwar, GA, Bakr, RFA, Helmy, NA, Kamel, OMHM, et al, 2012: Toxicological studies for some agricultural waste extract on mosquito larvae and experimental animals. Asian Pacif. J. Trop. Biomed. 23:55863.

Feyereisen, R, 2005: Insect cytochrome P450. In: Gilbert, L.I.; Iatrou, K. and Gill, S. (Eds.), Comperhensive Insect Physiology, Biochemistry, Pharm. Mol. Biol. Elsevier, Amsterdam. 
Gacar, F, Tasksn, V, 2009: Partial base sequence analysis of MdaE7 gene and aliesterase enzyme activities in the field collected populations of housefly (Musca domestica L.) from Mediterranean and Aegean Regions of Turkey. Pestic. Biochem. Physiol. 94:86-92.

Gusmäo, DS, Páscoa, V, Mathias, L, Vieira, I JC, Braz-Filho, R, et al, 2002: Derris (Lonchocarpus) игиси (Leguminosae) extract modifies the peritrophic matrix structure of Aedes aegypti (Diptera: Culicidae). Mem. Inst. Oswaldo Cruz, Rio de Janeiro 97, 3:371-5.

Habig, WH, Pabst, MJ, Jakoby, WB, et al, 1974: Glutathion S-transferases: The first enzymatic step in mercapturic acid formation. J. Biol. Chem. 249:7130-9.

Hansen, IG, Hodgson, E, 1971: Biochemical characteristics of insect microsomes. N- and Ode-methylation. Biochem. Pharma. 20:1569-78.

Harb, M, Faris, R, Gad, AM, Hafez, ON, Ramsy, R, et al, 1993: Research on lymphatic filariasis in the Ni-le Delta. Bull. WHO, 71:49-54.

Hassan, MM, Kamel, OMHM, 2016: Larvicidal and adulticidal effect of Rice straw extract against Culex pipiens (Diptera: Culicidae). Int. J. Cur. Res. 8, 1:25381-6.

Kamel, O M, Hassan, MM, Abd El-Baky, SM M, Hafez, JA, Hamed, MS, et al, 2005: Effect of the salinity and temperature on the larvicidal activity of some insecticidal agents the mosquito Ochlerotatus caspius (Diptera: Culicidae). J. Egypt. Acad. Soc. Environ. Develop. (A), 6, 2:30721.

Kamel, OMHM, Alghabban, AJ, Hassan, M M, et al, 2015: Evaluation of some medicinal plant extracts against Culex pipiens larvae and Biomphalaria alexandrina. Int. J. Rec. Adv. Multi. Res. 2, 12: 1105-9.

Kamel, OMHM, Hassan, MM, 2015: Latent effect of Cleome droserifolia ethanol extract on the development of Ochlerotatus caspius and Culex pipiens. Int. J. Rec. Adv. Multi. Res. 2, 12:1110-3.

Lane, RP, Crosskey, RW, 1993: Mosquitoes (Culicidae). In: Medical Insects and Arachnids. $1^{\text {st }}$ edition: Chapman and Hall, London.
Mikhail, MW, Al-Bursheed, KhM, Abd ElHalim, AS, Morsy, TA, 2009: Studies on mosquito borne diseases in Egypt and Qatar. J. Egypt. Soc. Parasitol. 39, 3:745-56.

Nathan, SS, Kalaivan, K, Chung, PG, et al, 2005: The effect of azadirachtin and nucleopolyhedrovirus on midgut enzymatic profile of Spodoptera litura Fab. (Lepidoptera: Noctuidae) Pestic. Biochem. Phys. 83, 1:46-57.

Osman, HM, Shayoub, ME, Babiker, EM, Munzir, ME, et al, 2014: The effect of Solenostemma argel leaves extract on lipid profile in albino rats. Inter. J. Develop. Res. 5, 3:3828-30.

Pavela, R, 2009: Larvicidal property of essential oils against Culex quiquefasciatus Say (Diptera: Culicidae). J. Ind. Crop. Prod. 30, 2:311-5.

Sharma, G, Kapoor, H, Chopra, M, Kumar, K, Agrawal, V, 2014: Strong larvicidal potential of Artemisia annua leaf extract against malaria (Anopheles stephensi Liston) and dengue (Aedes aegypti L.) vectors and bioassay-driven isolation of the marker compounds. Parasitol Res. 113, 1:197-209.

Simpson, DR, Bulland, DL, Linquist, DA, et al, 1964: A semimicro-technique for estimation of cholinesterase activity in boll weevils. Ann. Entomol. Soc. Amer. 57:367-71.

Terrier, LC, 1984: Induction of detoxification enzymes in insects. Ann. Rev. Entomol. 29:7188.

Van Asperen, K, 1962: A study of housefly esterase by means of sensitive colourmetric method. J. Insect. Physiol. 8:401-16.

Wang, Z, Zhao, Z, Abou-Zaid, MM, Arnason, JT, Liu, R, et al, 2014: Inhibition of insect Glutathion S-Transferase (GST) by conifer extracts. Arch. Insc. Biochem. Physiol. 87, 4:234-49.

Wilkinson, F, 1976: Insecticide Biochemists and Physiology (Plenum Press, New York, USA).

Wilson, ME, 1991: A World Guide to Infection: Diseases, Distribution, Diagnosis. Oxford, Oxford University Press. 